ARTICLE

\title{
Observations on the ontogeny of butterfish Stromateus stellatus larvae (Pisces: Stromateidae) off central Chile
}

\author{
Observaciones de la ontogenia del pampanito Stromateus stellatus (Pisces: Stromateidae) en Chile central
}

\author{
Guillermo A. Herrera' ${ }^{1, *}$, Francisca Zavala-Muñoz ${ }^{2}$ and Mauricio F. Landaeta ${ }^{2,3}$
}

${ }^{1}$ Facultad de Ciencias, Universidad Católica de la Santísima Concepción campus San Andrés, Alonso de Ribera 2850, Concepción,
Chile. *Autor corresponsal: gherrera@ucsc.cl
${ }^{2}$ Laboratorio de Ictioplancton (LABITI), Escuela de Biología Marina, Facultad de Ciencias del Mar y de Recursos Naturales,
Universidad de Valparaíso, Avenida Borgoño 16344, Reñaca, Viña del Mar, Chile. franazam@gmail.com,
mauricio.landaeta@uv.cl
32Centro de Observación Marino para Estudios de Riesgo del Ambiente Costero (COSTA-R), Universidad de Valparaíso, Chile

Resumen.- Aunque las larvas de pampanito Stromateus stellatus (familia Stromateidae) son observadas frecuentemente en aguas costeras del océano Pacífico suroriental, no existe una descripción formal de su desarrollo temprano. Utilizando muestras de ictioplancton de Chile central, se describe el desarrollo larval y se entregan observaciones de la osteología de la especie y de su distribución temporal en aguas costeras. Las larvas en preflexión tienen un hocico corto y redondeado y un patrón pigmentario característico. Transformaciones notorias durante el desarrollo, desde preflexión temprana hasta postflexión, son el aumento de la longitud preanal (desde menos de $40 \%$ a más de $50 \%$ de la longitud corporal) y profundidad corporal (desde 5 a 33\% de la longitud corporal). Inicialmente, desarrollan 3 melanóforos en el margen dorsal del cuerpo, pequeños melanóforos en el ángulo de la mandíbula y una hilera a lo largo del margen ventral de la cola. También se observan melanóforos de mayor tamaño en las zonas ventral y dorsal del intestino y sobre la vejiga gaseosa en estados tempranos de preflexión. Después de la flexión de la notocorda, las larvas desarrollan una leve pigmentación en las zonas laterales de la cola, y más oscura en la mitad anterior del cuerpo. Las larvas fueron recolectadas en Chile central, cercanas a la costa, en baja densidad (6 ind. $\left.100 \mathrm{~m}^{-3}\right)$, a mediados de primavera (octubre) y comienzos de verano (fines de diciembre hasta mediados de enero). Las larvas presentan las características generales de la familia, con un hocico redondeado y un cuerpo que incrementa notablemente en altura corporal y disminuye en distancia preanal durante el desarrollo; ellas poseen un patrón de pigmentación característico que las diferencia de otras especies cercanas. La ocurrencia de las larvas en el plancton registrada en Chile central es consistente con información de literatura sobre distribución larval previa y actividad reproductiva de adultos.

Palabras clave: Morfología, osteología, historia de vida temprana de peces

\begin{abstract}
Although larvae of the starry butterfish Stromateus stellatus (Family Stromateidae) are often observed in coastal waters of the southeastern Pacific Ocean, there is no formal description of the species' early development. Using ichthyoplankton samples collected off central Chile, the larval development, including observations on osteology of late postflexion stage larvae, and temporal differences in larval densities in nearshore waters are described. Preflexion larvae have a short, rounded snout and a distinctive pigment pattern. Notable transformations throughout the development from early preflexion to postflexion are the increase in preanal length from less than 40 to more than $50 \%$ of body length (BL) and in body depth from 5 to $33 \%$ BL. Initially, larvae develop 3 melanophores on the dorsal contour of the body, small melanophores at the jaw angle, and a row along the ventral margin of the tail. Large melanophores dorsal and ventral to the gut, intestine, and above the swim bladder are also present in early preflexion. After notochord flexion, larvae develop light pigmentation on the sides of the tail, and heavy pigmentation on the head and trunk. The larvae share the general shape of the family, with a body that increases notably in depth and preanal length during development; they present characteristic pigmentation that differentiates them from larvae of related species. The larvae were recorded in low density (less than 6 ind. $100 \mathrm{~m}^{-3}$ ) in the nearshore during mid-spring (October) and early summer (late December until mid-January) off central Chile. The occurrence of the larvae in the plankton recorded in central Chile is consistent with information from literature of larval distribution and reproductive activity in adults.
\end{abstract}

Key words: Morphology, osteology, early life history of fish

\section{INTRODUCTION}

The butterfish family Stromateidae contains 3 genera, Pampus, Peprilus and Stromateus, with about 17 species
(Nelson 2006, Marceniuk et al. 2016). This clade is supported by several synapomorphies, such as pterosphenoid expanding anteriorly, slightly separating 
from lateral ethmoid by a small cartilage; no teeth on palatine; anterior ends of bilateral fifth ceratobranchials articulating with one another via cartilaginous basibranchial; a single pair of uroneurals; proximal radials of first and second pterygiophores of the anal fin greatly elongated posterodorsally, flanking second to third, or fourth hemal spines; ventral arm of coracoid articulates with cleithrum above its ventral end; single dorsal fin; and pelvic fins always absent or rarely present only in young (Doiuchi et al. 2004).

Butterfishes are small to medium-size (ca., 30-50 cm) pelagic and epibenthic residents of tropical to temperate coastal seas. Juveniles are commonly associated with medusae and drifting macroalgae aggregated in frontal areas (Gray 1996, Castro et al. 2002, Pequeño et al. 2004). Butterfishes are compressed, moderately deep-bodied, with a rounded head. Pelvic fins are absent in adults, but present in some young. The dorsal fin is continuous and the anal fin has 2-6 spines with 30-50 soft rays (Nelson 2006). Scales are small, cycloid, and deciduous. Butterfishes are typically silvery on the flanks and grey to green or blue dorsally (Watson 1996). Many species, such as Pampus argenteus and $P$. punctatissimus, are targeted in commercial fisheries (Almatar et al. 2000, Shi et al. 2008).

Butterfishes are oviparous, with planktonic eggs and larvae. Eggs are spherical, 0.75-1.35 mm in diameter, with a smooth chorion, a homogeneous to partially (coarsely) segmented yolk, and 1-3 oil globules (usually 1, 0.17-0.45 mm) (Watson 1996). In Pampus punctatissimus embryonic development can last $15 \mathrm{~h}$ at $29-30^{\circ} \mathrm{C}$ (Almatar et al. 2000) and hatching occurs in a narrow range of salinities (2932) (Shi et al. 2008). Larvae hatch at small size ranges (ca., 1.7-2.8 mm, D’Vincent et al. 1980, Almatar et al. 2000) with unpigmented eyes and unformed mouth. The larval stage lasted for 40 days in specimens reared at $27-30^{\circ} \mathrm{C}$ (Almatar et al. 2000).

Starry butterfish Stromateus stellatus Cuvier, 1829 is the only stromateid species in the Southeastern Pacific off Chile (Pequeño 1997). It is a serial spawner that reaches first maturity at $21 \mathrm{~cm}$ total length (Carocca \& Chong 2010). The eggs are yet to be described. Larvae, although never formally described, have been collected throughout the year in Bahía Concepción, central Chile, where they were the most abundant species in a year round study, with peaks of abundance during spring, summer, and winter months (Aron 1980). They were also collected over the shelf in upwelling zones in central Chile (HernándezMiranda et al. 2003, Landaeta et al. 2008) and in fjords throughout southern Chile (Balbontín \& Bernal 2005, Bustos et al. 2008, 2011).

The main goals of this work were to describe the larval development of the Pacific butterfish, S. stellatus from Chilean waters, and to provide an osteological characterization of its postlarval stages. Temporal variations of local larval densities off central Chile were also described briefly.

\section{MATERIALS AND METHODS}

Preflexion, flexion and postflexion stages (after Kendall et al. 1984) of Stromateus stellatus larvae, in the size range from 2.7 to $10.0 \mathrm{~mm}$ (BL), are described, focusing on changes in body shape, pigmentation, and fin development. A total of 117 larvae were identified using the serial method (Neira et al. 1998). The body length (BL) corresponds to notochord length (NL) in preflexion and to standard length (SL) in flexion and postflexionstage larvae. Morphometric measurements of body depth (BD), head length (HL), and preanal length (PAL), were obtained under a stereomicroscope with a scale and converted to percentage of BL.

For the description of the temporal distribution of larval S. stellatus off central Chile during the primary spawning period, spring-summer, collections of zooplankton samples were utilised. A total of 50 night-time ichthyoplankton samplings were carried out in shallow nearshore waters ( $<1 \mathrm{~km}$ offshore, $<30 \mathrm{~m}$ bottom depth) off Montemar, Valparaíso Bay, and El Quisco Bay during September 2015 to February 2016 and September 2016 to February 2017 on a weekly basis. Every night sampling comprised 3 hauls with a Bongo net (60 cm diameter, 300 $\mu \mathrm{m}$ mesh) equipped with a TSK flowmeter (The TsurumiSeiki Co., Ltd. Tsurumi Ku, Yokohama, Japan) to estimate the filtered volume. A total of 300 samples were obtained. The samples were fixed in 5\% buffered formalin, and transferred to $95 \%$ ethanol after $24 \mathrm{~h}$. Densities of larval S. stellatus were standardised to individuals per $100 \mathrm{~m}^{3}$. A detailed description of the sampling procedure was given by Díaz-Astudillo et al. (2017).

For the osteological characterization of postflexion larvae, 3 specimens between 14.5 and $16.4 \mathrm{~mm} \mathrm{SL}$, from samples collected in Montemar during January 2017, were cleared and stained following Dingerkus \& Uhler (1977). These processed specimens were photographed using a Leica ${ }^{\circledR}$ EZ 4 HD stereomicroscope with an integrated camera. Photos were edited and labelled using image edition program GIMP 2.8.16. 


\section{RESULT}

\section{LARVAL DESCRIPTION}

\section{GENERAL MORPHOLOGY}

The smallest Stromateus stellatus larva (2.7 mm NL) sampled for this study has an elongate body ( $5 \%$ of BL at the anus) and a preanal distance of 39\% BL. Behind the anus, the body tapers gradually. The larva has fully pigmented eyes, a blunt head and a rounded snout (Fig.
1A). Through preflexion stage the preanal length remains similar but the body depth begins to increase, to $7 \%$ at $4.3 \mathrm{~mm}$ BL (Fig. 1B), a process that continues throughout development.

\section{Pigmentation}

The pigmentation includes 3 large dorsal dendritic melanophores on the body, evenly spaced from the level of the anus to the middle of the tail. There is 1 (rarely 2) small melanophore on the nape, which becomes embedded

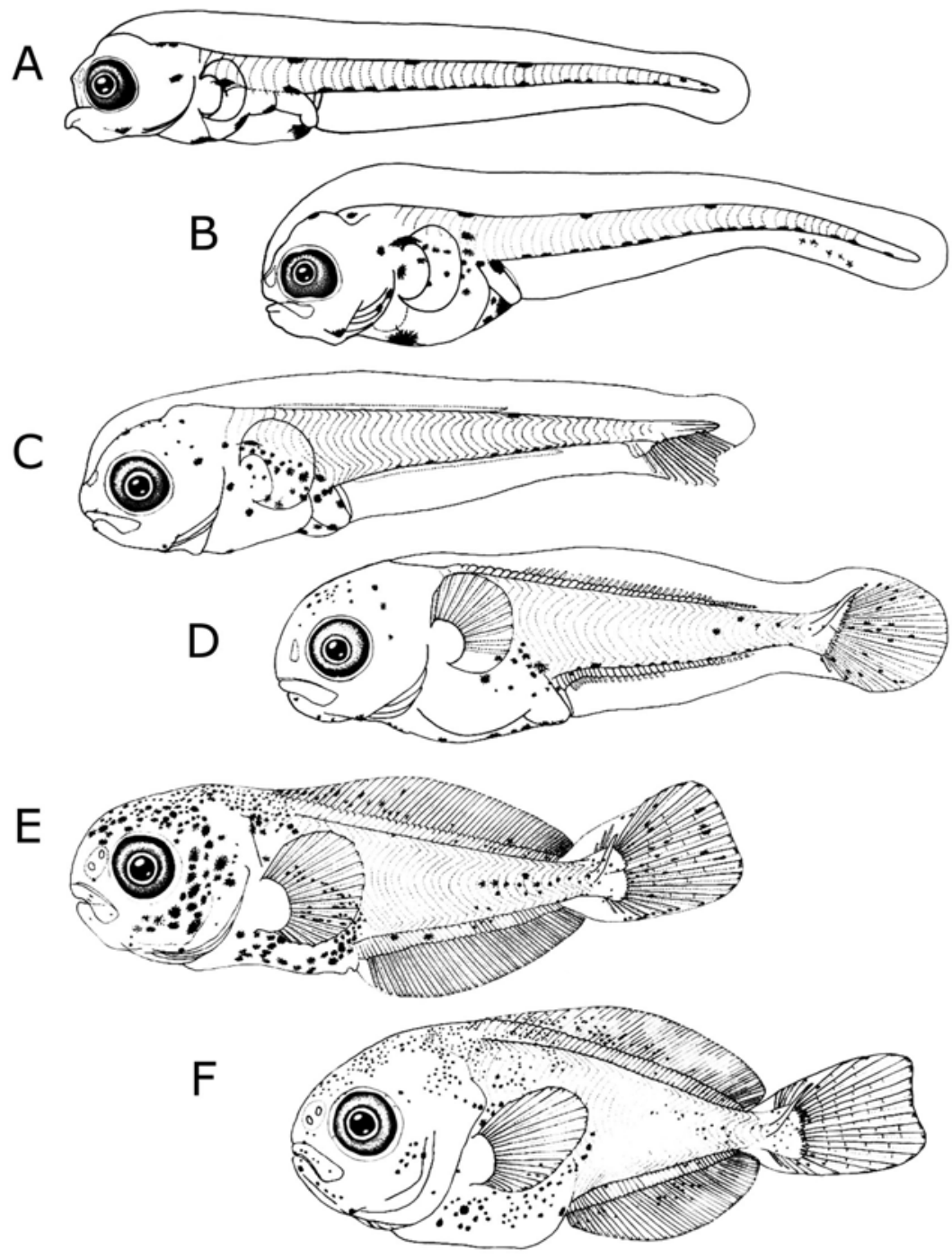

Figure 1. Larvae of Stromateus stellatus: A) Preflexion, $2.7 \mathrm{~mm} \mathrm{NL}$; B) Preflexion, $4.4 \mathrm{~mm} \mathrm{NL}$; C) Flexion, $6.8 \mathrm{~mm} \mathrm{NL}$; D) Flexion, $8.0 \mathrm{~mm} \mathrm{SL;} \mathrm{E)}$ Postflexion, 8.7 mm SL; F) Postflexion, 10.0 mm SL / Larvas de Stromateus stellatus: A) Preflexión, 2,7 mm LN; B) Preflexión, 4,4 mm LN; C) Flexión, 6,8 mm LN; D) Flexión, 8,0 mm LE; E) Postflexión 8,7 mm LE; F) Postflexión 10,0 mm LE 
early on during development. The ventral pigmentation from the anus to the end of the notochord, is composed of a row of small melanophores irregularly spaced along the contour of the tail, as there are fewer melanophores than myomeres. Other pigmentation that appears during preflexion stage includes internal melanophores on the side of the head, over the swim bladder, and a single and small melanophore at the jaw angle. Large external dendritic melanophores develop under the liver, stomach, intestine, and on the finfold anterior to the anus.

During early flexion stage (Fig. 1C) PAL and BD increase (to $42 \% \mathrm{BL}$ and $12 \% \mathrm{BL}$, respectively). Pigmentation develops at different positions: paired melanophores in front of the liver, which become embedded through development, small internal and external melanophores on the sides of the stomach and intestine, and melanophores on the brain case and on the finfold anterior to the anus.

Notochord flexion is observed in specimens from 5.6 to $7.7 \mathrm{~mm}$ BL (Figs. 1C and 1D), during which the preanal length continues to increase (42 to $46 \% \mathrm{BL}$ ). The body becomes deeper (12 to $19 \% \mathrm{BL}$ ), which is enhanced even more with the development of the pterygiophores of dorsal and anal fins. The dorsal and the anal fins begin to form during flexion. Anlagen of these fins appear anteriorly during early preflexion and continue forming posteriorad. The pterygiophores and rays of the dorsal and anal form as the anlagen continue extending posteriorly (Fig. 1D). Pectoral fin rays begin to develop during late flexion stage.

During notochord flexion, the 3 distinctive melanophores on dorsal contour of the body disappear. The melanophores on the head, dorsally and to the sides increase progressively. Moreover, small melanophores form on the gular area. Scattered melanophores appear on the side of the tail and between the caudal fin rays.

During postflexion stage (Figs. 1E, 1F) the body keeps growing deeper, reaching over $30 \% \mathrm{BL}$ (at the anus level), and the preanal distance increases in length, exceeding $50 \% \mathrm{BL}$. The development of the dorsal and anal fins rays, as well as the procurrent rays (6 to 7 dorsal and ventral), is also completed during these stages. There is a significant increase in the dorsal pigmentation as small melanophores develop on top and behind the head, among the dorsal fin rays, and on the anterior and posterior dorsal pterygiophores. Other melanophores appear in the opercular region, on the cheek, on the sides of the gut, on the lower jaw, and a few scattered on the anal fin.

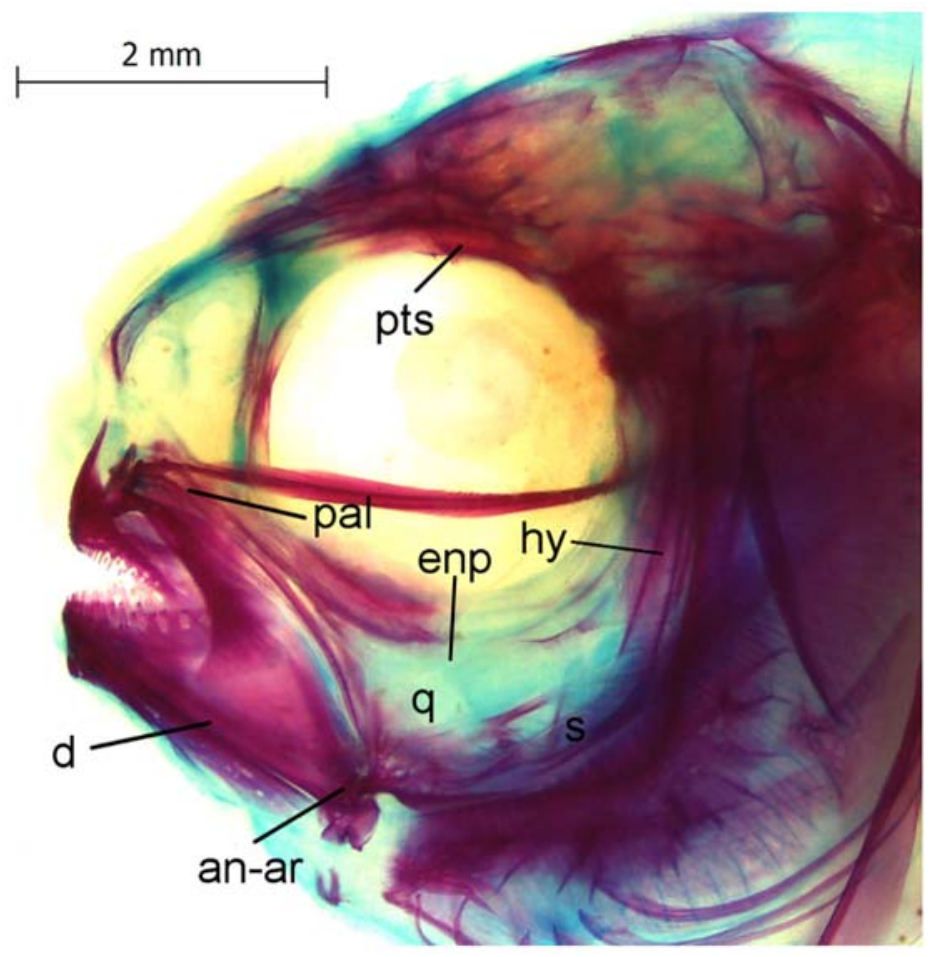

Figure 2. Skull of a cleared and stained Stromateus stellatus postflexion larva (16.4 $\mathrm{mm} \mathrm{SL})$. Labels: an-ar, anguloarticular complex; d, dentary; enp, endopterygoid; hy, hyoid; q, quadrate; pal, palatine; pts, pterosphenotic; s, symplectic / Cráneo teñido y aclarado de una larva en postflexión de Stromateus stellatus (16,4 mm LE). Etiquetas: an-ar, complejo anguloarticular; d, dentario; enp, endopterigoideo; hy, hioideo; q, cuadrado; pal, palatino; pts, pterosfenótico; s, simpléctico 


\section{OSTEOLOGICAL CHARACTERIZATION}

Skeletal characters of the head (Fig. 2), fin support structure of dorsal, anal and caudal fins (Figs. 3 and 4), infraorbital series (Fig. 5), pelvic girdle (Fig. 6), and opercular bones (Fig. 7), were obtained from cleared and stained postflexion specimens. At that stage, several osteological characters used by Doiuchi et al. (2004) to study the phylogenetic relationships of the stromateoid fishes are recognized. Among these, characters displayed by Stromateus are: the quadrate and the endopterygoid are in direct contact in the suspensorium, although they are not fully ossified (Fig. 2); there is an enlarged second infraorbital (Fig. 5); the ventral end of the coracoid articulates above the tip of the cleithrum (Fig. 6); the pectoral fin radials are well separated from each other; a pelvic bone can be seen, with no signs of rays (Fig. 6); and the first 3 proximal pterygiophores of the anal fin are fused and greatly elongated posterodorsally, reaching to the 4th hemal spine of the caudal vertebrae.
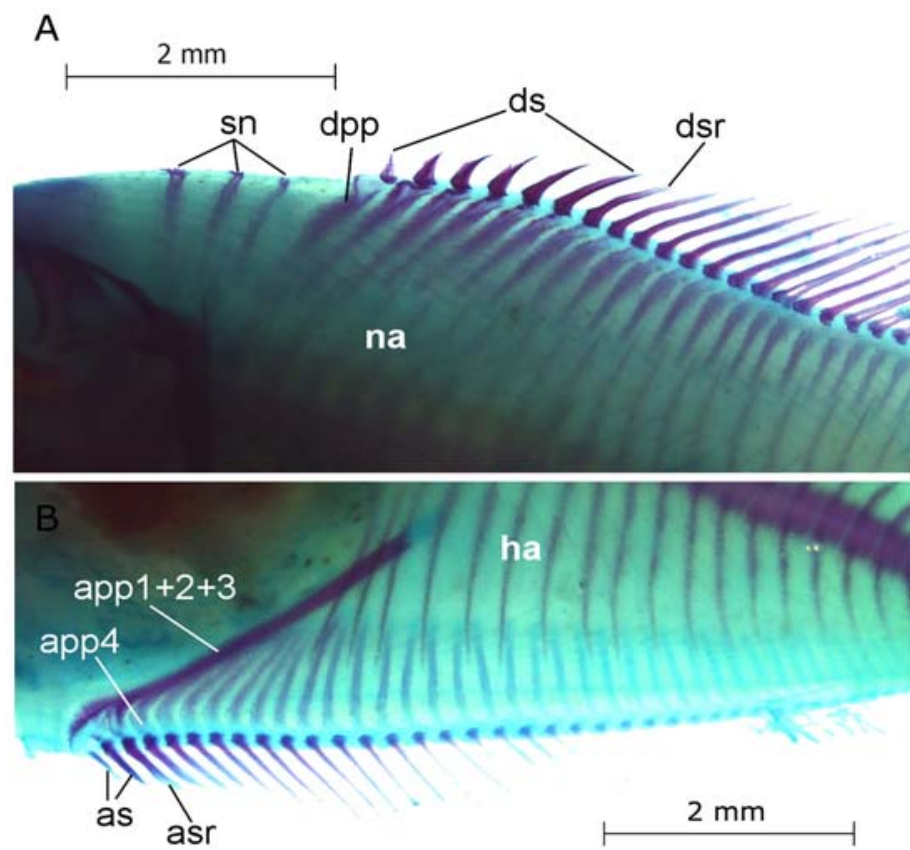

Figure 3. Dorsal (A) and anal (B) fins of a Stromateus stellatus post flexion larva (15.6 $\mathrm{mm} \mathrm{SL}$ ). Labels: app, anal proximal pterygiophore; as, anal spine; asr, anal soft ray; dpp, dorsal proximal pterygiophore; ds, dorsal spine; dsr, dorsal soft ray; ha, hemal arches; na, neural arches; sn, supraneural bones / Aletas dorsal (A) y anal (B) de una larva en postflexión de Stromateus stellatus (15,6 mm LE). Etiquetas: app, pterigióforo proximal anal; as, espina anal; asr, radio anal; dpp, pterigióforo proximal dorsal; ds, espina dorsal; dsr, radio dorsal; ha, arcos hemales; na, arcos neurales; sn, huesos supraneurales

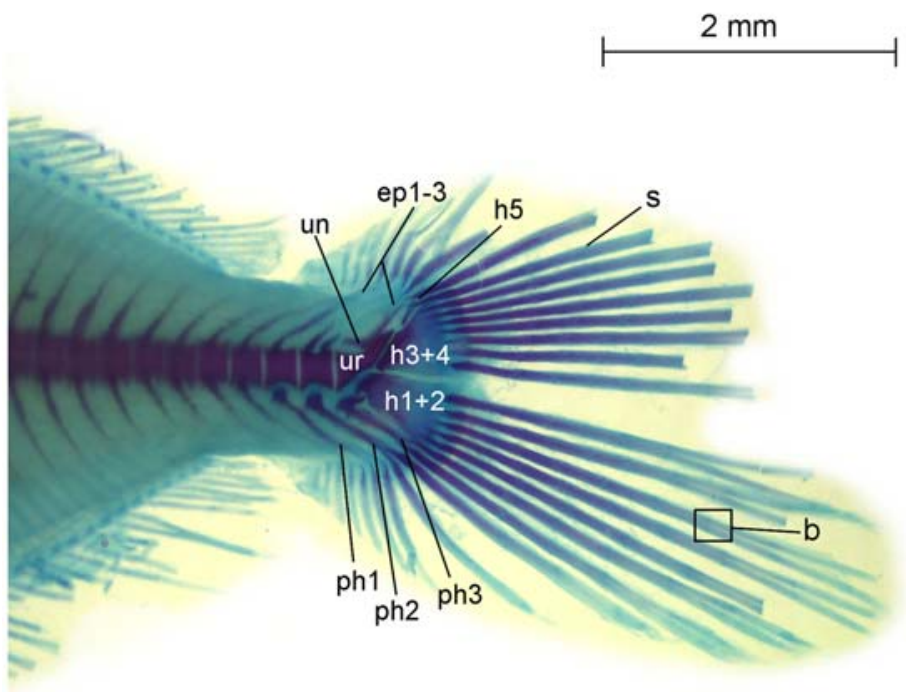

Figure 4. Caudal fin of a Stromateus stellatus postflexion larva (16.4 mm SL). Labels: b, branches; ep, epural; $h$, hypural; ph, parahypural; s, segments; un, uroneural; ur, urostyle / Aleta caudal de una larva en Postflexión de Stromateus stellatus $(16,4 \mathrm{~mm}$ LE). Etiquetas: b, ramificaciones; ep, epural; h, hipural; ph, parahipural; $\mathrm{s}$, segmentos; un, uroneural; ur, urostilo 


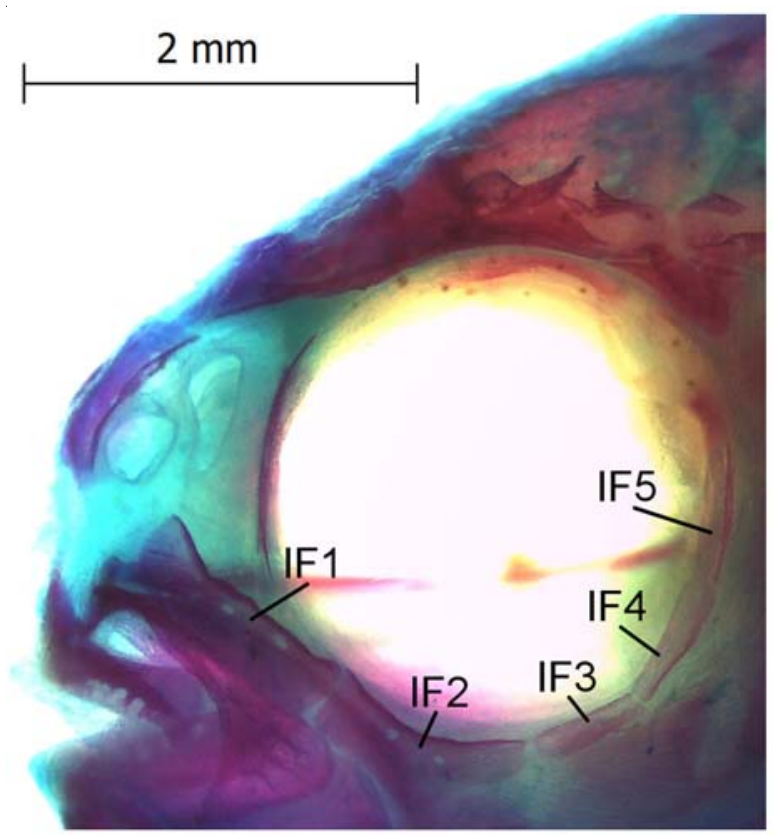

Figure 5. Infraorbital bones of a Stromateus stellatus postflexion larva (15.6 mm SL). Labels: IF1-5, first (=lachrymal) to fifth infraorbitals / Infraorbitales de una larva en Postflexión de Stromateus stellatus (15,6 mm LE). Etiquetas: IF1-5, primero (=lagrimal) a quinto infraorbitales

Figure 6. Pectoral fin of a Stromateus stellatus postflexion larva (16.4 mm SL). Labels: cl, cleithrum; co, coracoid; mcl, metacleithrum; p, pelvic bone; pos, preopercular spines; pp, pectoral-fin pterygiophores; pr, pectoral-fin radials; r, pectoralfin rays; sc, supracleithrum / Aleta pectoral de una larva en Postflexión de Stromateus stellatus (16,4 mm LE). Etiquetas: $\mathrm{cl}$, cleithrum; co, coracoide; mcl, metacleitro; $p$, hueso pélvico; pos, espinas preoperculares; pp, pterigióforos de la aleta pectoral; pr, radiales de la aleta pectoral; $r$, radios de la aleta pectoral; sc, supracleitro

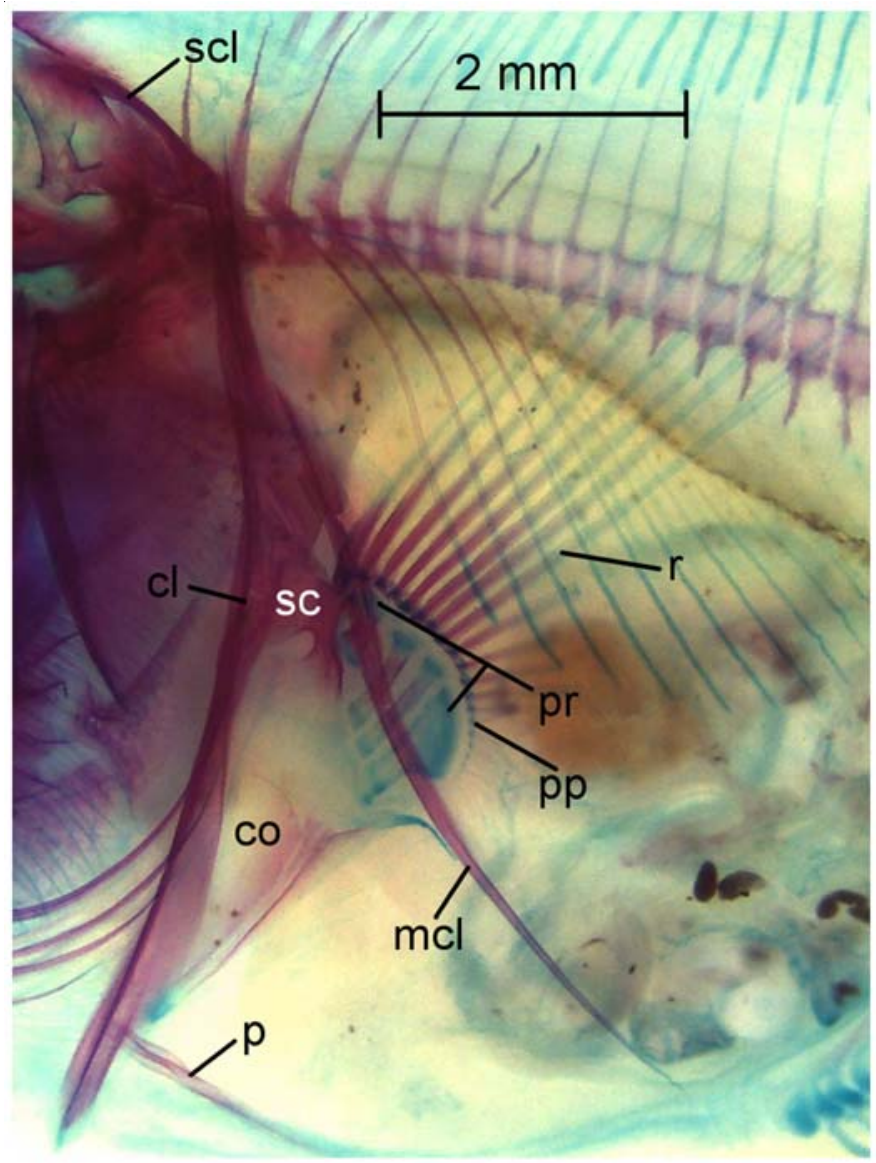




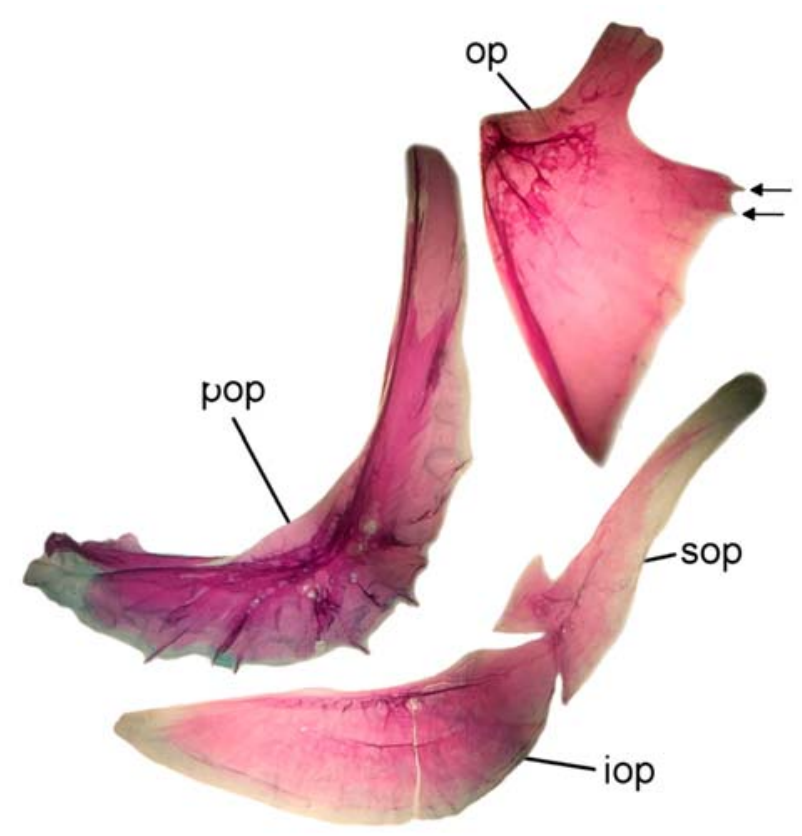

Other relevant features from cleared and stained specimens are: the first anal proximal pterygiophore has no spine (Fig. 4); the dentary has a single row of small caniniform teeth, with 4-5 bicuspid teeth at the posterior end of the row (Fig. 6); an opercle with 2 spines (Fig. 7), a preopercle with 3 smaller spines on the lower margin and 7-8 on the posterior margin [see spine development in larvae from $15.6 \mathrm{~mm}$ (Fig. 7) to $16.8 \mathrm{~mm} \mathrm{SL} \mathrm{(Fig.} \mathrm{3)].} \mathrm{Counts}$ of dorsal and anal fin elements in 3 selected specimens were: D V-VI, 40-42, A II, 40-42. There are 8+6 segmented and branched caudal rays; there also is a single pair of uroneurals (Fig. 5). The position of supraneurals and pterigyophores in the dorsal fin varied among individuals. There was also variation in anal fin structure. The formulae of dorsal and anal fin, following Jawad \& Jig (2016), in 2 specimens are given as a reference.

\section{Specimen 003}

Dorsal: $1 \mathrm{~S}$ - N - 1S - 1S, $1 \mathrm{P}$ - 2P - 1(9)P - 2P - 1(2)P - 2(2)P - $1 \mathrm{P}$ - 2(2)P - $1 \mathrm{P}-2(2) \mathrm{P}-1 \mathrm{P}-2 \mathrm{P}-1 \mathrm{P}-2 \mathrm{P}-1 \mathrm{P}-2(6) \mathrm{P}$

Anal: 8P - C - 2P - 3P - 2P - 1P - 3P - 1P - 2(5)P - 1P - 2(6)P

\section{Specimen 009}

Dorsal: $1 \mathrm{~S}$ - N - 2S - 2(2)P - 1(9)P - 2P - 1(2)P - 2(2)P - 1P - 2(3)P - $1 \mathrm{P}-2 \mathrm{P}-1 \mathrm{P}-2 \mathrm{P}-1 \mathrm{P}-2 \mathrm{P}-1 \mathrm{P}-2 \mathrm{P}-1(2) \mathrm{P}-2 \mathrm{P}-1 \mathrm{P}$ $-1 \mathrm{P}-2(2) \mathrm{P}$

Anal: $10 \mathrm{P}$ - C - 2(4)P - 1P - 2(2)P - 1P - 2(3)P - 1P - 2(3)P $-1 \mathrm{P}-2 \mathrm{P}-1 \mathrm{P}$
Figure 7. Opercular bones of a Stromateus stellatus postflexion larva (15.6 $\mathrm{mm} \mathrm{SL}$ ). Labels: iop, interopercle; op, opercle; pop, preopercle; sop, subopercle. Arrows indicate the position of the opercular spines / Serie opercular de una larva en postflexion de Stromateus stellatus (15,6 mm LE). Etiquetas: iop, interopérculo; op, opérculo; pop, preopérculo; sop, subopérculo. Las flechas indican la posición de las espinas operculares

\section{TeMPORAL DISTRIBUTION OF LARVAL BUTTERFISH OFF CENTRAL ChILE}

A total of 117 specimens were collected throughout the study period. Larvae were scarce in nearshore waters off El Quisco and Montemar, central Chile, as densities never exceeded 6 ind. $100 \mathrm{~m}^{-3}$. Two peaks (2-5 ind. $100 \mathrm{~m}^{-}$ ${ }^{3}$ ) were noticeable in the time series, one during austral mid-Spring (early to mid-October) and a second, not evident at Montemar, during early summer (late December to early January). In general, density peaks seem to coincide at the three localities (Fig. 8).

\section{Discussion}

The larvae of Stromateus stellatus can be easily identified by their shape and pigment pattern, and by meristic characteristics (dorsal 47-50, anal 41-44, pectoral 19-24, vertebrae 42-43). The most noticeable change throughout development is the increase in body height, from less than 5\% BL in early preflexion stage to more than $30 \% \mathrm{BL}$ in late postflexion stage. The 3 melanophores on the dorsal contour of the body during pre- and flexion stages are similar to those found in preflexion stages of larval mote sculpin Normanichthys crockeri, but this latter species has more slender larvae and have more dorsal pigment (Balbontín \& Pérez 1980). Larvae of pinguipedids Pinguipes chilensis and Prolatilus jugularis have similar body shape during preflexion stage, but these species lack the type of dorsal pigmentation on the head and trunk (Vélez et al. 2003) observed in Stromateus. 


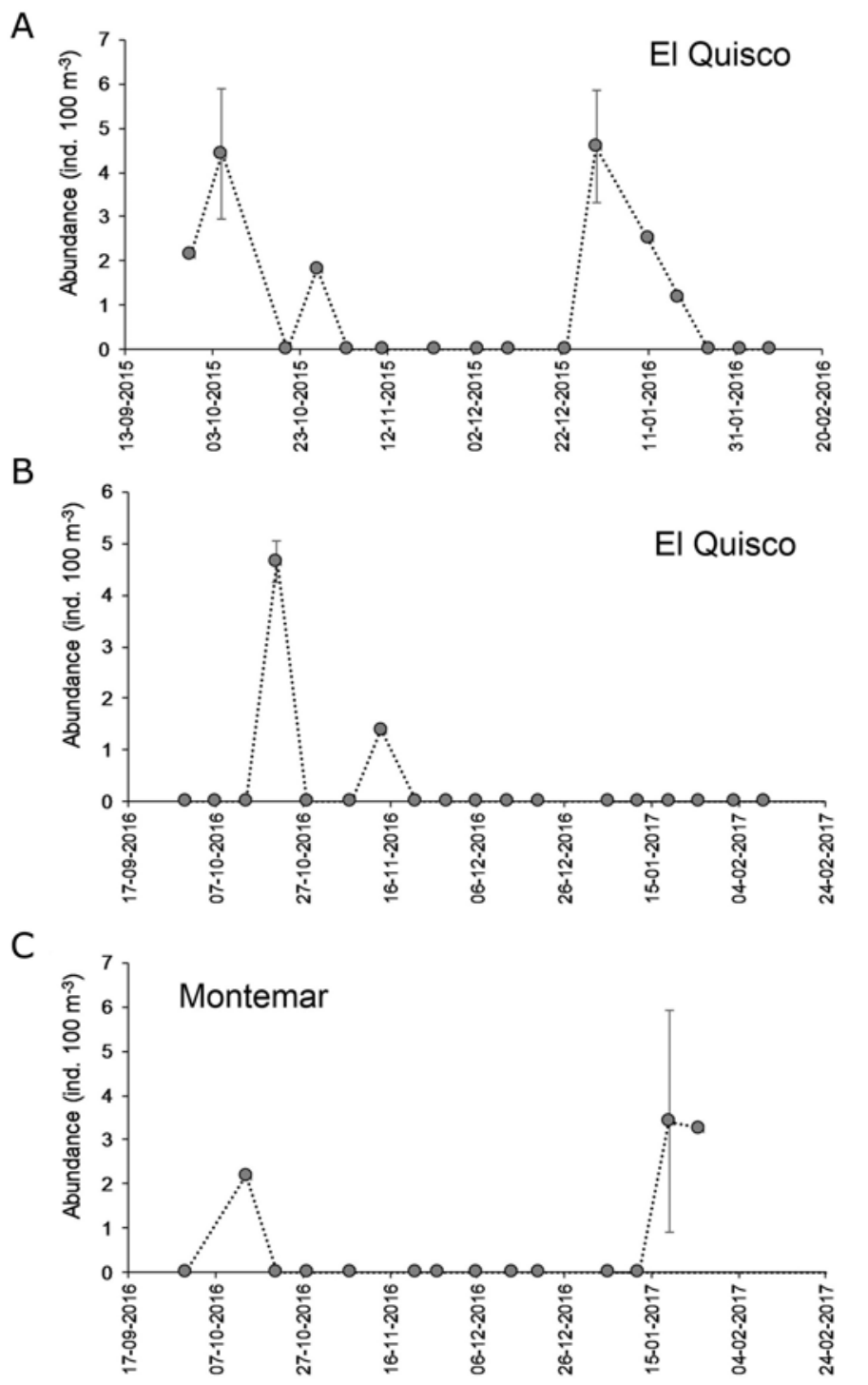

Figure 8. Temporal differences in densities (ind. $100 \mathrm{~m}^{-3}$ ) of larval butterfish Stromateus stellatus off central Chile throughout the respective sampling periods: A) El Quisco, 2015-2016; B) El Quisco, 2016-2017; C) Montemar, 2016-2017 / Variabilidad temporal de la densidad larval (ind. $100 \mathrm{~m}^{-3}$ ) del pampanito Stromateus stellatus en Chile central. A) El Quisco, 20152016; B) El Quisco, 2016-2017; C) Montemar, 2016-2017

The larvae of S. stellatus are similar to the ones of other stromateid fishes, such as Peprilus simillimus (D’Vincent et al. 1980, Horn 1984), P. burti, P. triacanthus and P. paru (Aboussan 1983, Ditty \& Truesdale 1983, Fahay 1983, 2007), S. fiatola (Aboussouan 1983), and $S$. brasiliensis (Cassia \& García de la Rosa 1994). For example, they also exhibit a short and rounded snout, a body that becomes increasingly deep with development, and the preanal length that shortens with the coiling of the gut (Watson 1996). There are, however, differences in the pigmentation pattern and its transformation during development. The three characteristic dorsal melanophores described in S. stellatus, for instance, are also found in early stages of $S$. brasiliensis (2.8 mm NL), but they disappear at larger sizes (Cassia \& García de la Rosa 1994); $P$. simillimus, $P$. burti, P. triacanthus, and P. paru have only one dorsal melanophore (D'Vincent et al. 1980, Ditty \& Truesdale 1983), and S. fiatola has none (Aboussouan 1983). There are differences in the structure of preopercular spines; the larvae of S. stellatus develop 8-10 spines, 3 of 
which form anteriorly, on the ventral margin of the preopercular bone, a feature not observed in Peprilus or Pampus. The formation of a pelvic bone was recorded, a feature that is also found in S. fiatola (Horn 1973). As the pelvic fin is absent in the adults, this might represent a regressive attribute for the genus.

The presence of larval S. stellatus in nearshore waters off central Chile during spring and summer is consistent with the summer maximum reproductive activity of adults reported by Carocca \& Chong (2010). Larval S. stellatus were first recorded by Aron (1980) in the Bay of Concepción $\left(36^{\circ} 41^{\prime} \mathrm{S}\right)$; they were caught throughout a year of sampling and were the most abundant species in the stations inside and outside of the bay. At other locations and times, however, densities were low, ranging from 0.4 (Landaeta et al. 2008) to 5.3 larvae $100 \mathrm{~m}^{-3}$; these included locations nearshore and over the shelf off central Chile during winter (Hernández-Miranda et al. 2003, Landaeta et al. 2008), and inner waters of north and south Patagonia $\left(41^{\circ} 30^{\prime}-46^{\circ} \mathrm{S}\right)$ during spring (Balbontín \& Bernal 2005, Bustos et al. 2008, 2011). Thus, the open near shore environment seems not to be important as a nursery area for this species, compared to the larval abundances of other species, such as the cryptobenthic Auchenionchus crinitus (>300 ind. $100 \mathrm{~m}^{-3}$; Díaz-Astudillo et al. 2017), or the small pelagic Engraulis ringens (>600 ind. $100 \mathrm{~m}^{-3}$; Díaz-Astudillo et al. 2017). It remains to be determined whether the species spawns mainly in more closed embayments along its full range of distribution.

\section{ACKNOWLEDGMENTS}

Part of the biological material was collected and funded by FONDECYT 1150296, granted to MFL. Additional support was provided by DIN02/214 (Universidad Católica de la Santísima Concepción) granted to GAH. We thank the valuable suggestions made by four anonymous reviewers of the manuscript.

\section{LITERATURE CITED}

Aboussouan A. 1983. Contribution à l'étude des larves pélagiques du sousordre des Stromateoidei (Pisces, Perciformes). Cybium 7(4): 1-24.

Almatar S, KA Elah \& T Abu-Rezq. 2000. Larval developmental stages of laboratory-reared silver pomfret, Pampus argenteus. Ichthyological Research 47(2): 137-141.

Aron A. 1980. Taxonomía, distribución y abundancia de larvas de peces en Bahía Concepción (3640’S; 6302’W) Chile. Memoria de Biólogo Marino, Universidad de Concepción, Concepción, 66 pp.
Balbontín F \& R Bernal. 2005. Cambios estacionales en la composición y abundancia del ictioplancton de los canales australes entre el Golfo Corcovado y Golfo Elefantes, Chile. Ciencia y Tecnología del Mar 28(1): 99-111.

Balbontín F \& R Pérez. 1980. Descripción de los estados larvales de Normanichthys crockeri Clark (Perciformes: Normanichthyidae) del área de Valparaíso, Chile. Revista de Biología Marina 17(1): 81-95.

Bustos CA, MF Landaeta \& F Balbontín. 2008. Environmental effects on the spatial variability of the ichthyoplankton from southern Chile during November 2005. Revista Chilena de Historia Natural 81: 205-219.

Bustos CA, MF Landaeta \& F Balbontín. 2011. Ichthyoplankton spatial distribution and its relation with water column stratification in fjords of southern Chile (46 $48^{\prime}-50^{\circ} 09^{\prime} S$ ) in austral spring 1996 and 2008. Continental Shelf Research 31: 293-303.

Carocca C \& J Chong. 2010. Ovarian activity in Pacific butterfish, Stromateus stellatus in the coast off Biobío region, Chile. Revista de Biología Marina y Oceanografía 45(S1): 751-755.

Cassia MC \& SB García de la Rosa. 1994. Características diferenciales del desarrollo larval de Stromateus brasiliensis, y su distribución en el Atlántico sur occidental. Frente Marítimo, Montevideo 15: 157-162.

Castro JJ, JA Santiago \& AT Santana. 2002. A general theory on fish aggregation to floating objects: An alternative to meeting point hypothesis. Reviews in Fish Biology and Fisheries 11: 255-277.

Díaz-Astudillo M, MI Castillo, MA Cáceres, G Plaza \& MF Landaeta. 2017. Oceanographic and lunar forcing affects nearshore larval fish assemblages from temperate rocky reefs. Marine Biology Research 13: 1015-1026.

D’Vincent S, HG Moser \& EH Ahlstrom. 1980. Description of the larvae and early juveniles of the Pacific butterfish, Prepilus simillimus (family Stromateidae). CalCOFI Reports 21: 172-179.

Dingerkus G \& LD Uhler. 1977. Enzyme clearing of alcian blue stained whole small vertebrates for demonstration of cartilage. Stain Technology 52(4): 229-232.

Ditty JG \& FM Truesdale. 1983. Comparative larval development of Peprilus burti, P. triacanthus and P. paru (Pisces: Stromateidae) from the western North Atlantic. Copeia 2: 397-406.

Doiuchi R, T Sato \& T Nakabo. 2004. Phylogenetic relationships of stromateoid fishes (Perciformes). Ichthyological Research 51: 202-212. <doi: 10.1007/ s10228-004-0216-8>

Fahay MP. 1983. Guide to the early stages of marine fishes occurring in the western North Atlantic Ocean, Cape Hatteras to the Southern Scotian Shelf. Journal of Northwestern Atlantic Fisheries Science 4: 1-423. 
Fahay MP. 2007. Early stages of fishes in the Western North Atlantic Ocean (Davis Strait, Southern Greenland and Flemish Cap to Cape Hatteras). Volume 2: Scorpaeniformes through Tetraodontiformes, pp. 932-1696. Northwest Atlantic Fisheries Organization, Nova Scotia.

Gray CA. 1996. Intrusions of surface sewage plumes into continental shelf waters: Interactions with larval and presettlement juvenile fishes. Marine Ecology Progress Series 139: 31-45.

Hernández-Miranda E, AT Palma \& FP Ojeda. 2003. Larval fish assemblages in nearshore coastal waters off central Chile: temporal and spatial patterns. Estuarine, Coastal and Shelf Science 56: 1075-1092.

Horn MH. 1973. Systematic comparison of the Stromateid fishes Stromateus brasiliensis Fowler and Stromateus stellatus Cuvier from coastal South America, with a review of the genus. Bulletin of the British Museum of Natural History, Zoology 24(7): 317-339.

Horn MH. 1984. Stromatoidei: Development and relationships. In: Moser HG, WJ Richards, DM Cohen, MP Fahay, AW Kendall Jr \& SL Richardson (eds). Ontogeny and systematics of fishes. American Society of Ichthyologists and Herpetologists, Special Publication 1: 620-628.

Jawad LA \& L Jig. 2016. Comparative osteology of the axial skeleton of the genus Pampus (Family: Stromateidae, Perciformes). Journal of the Marine Biological Association of the United Kingdom 97(2): 1-10.

Kendall AW Jr, EH Ahlstrom \& HG Moser. 1984. Early life history stages of fishes and their characters. In: Moser HG, WJ Richards, DM Cohen, MP Fahay, AW Kendall Jr \& SL Richardson (eds). Ontogeny and systematics of fishes. American Society of Ichthyologists and Herpetologists, Special Publication 1: 11-22.
Landaeta MF, R Veas, J Letelier \& LR Castro. 2008. Larval fish assemblages off central Chile upwelling ecosystem. Revista de Biología Marina y Oceanografía 43(3): 569-584.

Marceniuk AP, R Caires, R Siccha-Ramirez \& C Oliveira. 2016. Review of the harvestfishes, genus Prepilus (Perciformes: Stromateidae), of the Atlantic coast of South America. Zootaxa 4098(2): 311-332. <doi: 10.11646/ zootaxa.4098.2.6>

Neira F, A Miskiewicz \& T Trnski. 1998. Larvae of temperate Australian fishes: Laboratory guide for larval fish identification, 474 pp. University of Western Australia Press, Nedlans.

Nelson JS. 2006. Fishes of the world, 601 pp. John Wiley \& Sons, Hoboken.

Pequeño G. 1997. Peces de Chile. Lista sistemática revisada y comentada: Addendum. Revista de Biología Marina Valparaíso 32(2):77-94.

Pequeño G, D Farías, M Thiel \& I Hinojosa. 2004. Fishes associated to drifting macroalgae in Aysen, Chile. Revista de Biología Marina y Oceanografía 39(2): 93-99.

Shi Z, X Huang, R Fu, H Wang, H Luo, B Chen, M Liu \& D Zhang. 2008. Salinity stress on embryos and early larval stages of the pomfret Pampus punctatissimus. Aquaculture 275(1-4): 306-310.

Vélez JA, W Watson, EM Sandknop \& W Arntz. 2003. Larval development of the Pacific sandperch (Prolatilus jugularis) (Pisces: Pinguipedidae) from the Independencia Bight, Pisco, Peru. Journal of the Marine Biological Association of the United Kingdom 83: 1137-1142.

Watson W. 1996. Stromateidae: Butterfishes. In: Moser HG (ed). The early stages of fishes in the California Current Region. CalCOFI Atlas 33: 1318-1321.

Received 30 January 2018 and accepted 28 May 2018

Contributors to the editor: Ph.D Julian Döring \& Ph.D William Watson 